\title{
The Relationship Between Monocyte Count to High-density Lipoprotein Ratio and Severity of Inflammation in Aggressive Periodontitis: A Retrospective Analysis Agresif Periodontitis Hastalarında Enflamasyon Şiddeti ile Monosit-yüksek Yoğunluklu Lipoprotein Oranı Arasındaki llişki: Retrospektif Analiz \\ (1D Berceste Güler ${ }^{1}$, (1) Ezgi Doğan ${ }^{1}$, (1) Kevser Onbaşı² \\ ${ }^{1}$ Kütahya University of Health Sciences Turkey, Faculty of Dentistry, Department of Periodontology, Kütahya, Turkey \\ ${ }^{2}$ Kütahya University of Health Sciences Turkey, Faculty of Medicine, Department of Endocrinology, Kütahya, Turkey
}

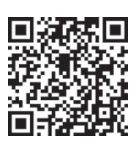

Keywords

Aggressive periodontitis, monocytes, highdensity lipoproteins, diagnosis

Anahtar Kelimeler

Agresif periodontitis, monosit, lipoprotein, teşhis

Received/Geliş Tarihi : 25.04.2019

Accepted/Kabul Tarihi : 09.06.2020

doi:10.4274/meandros.galenos.2020.41033

Address for Correspondence/Yazışma Adresi: Berceste Güler MD,

Kütahya University of Health Sciences

Turkey, Faculty of Dentistry, Department of

Periodontology, Kütahya, Turkey

Phone : +90 5059359207

E-mail : berceste43@gmail.com

ORCID ID: orcid.org/0000-0003-2440-6884

(C) Meandros Medical and Dental Journal, Published by Galenos Publishing House.

This is article distributed under the terms of the

Creative Commons Attribution NonCommercial 4.0

International Licence (CC BY-NC 4.0).

\section{Abstract}

Objective: Hyperlipidemia is a known cardiovascular disease risk factor. A common biological mechanism between systemic diseases, such as cardiovascular diseases, and periodontal diseases has been suggested. This study aimed to examine the association between blood lipid profile and the severity of aggressive periodontitis (AgP).

Materials and Methods: A total of 32 systemically healthy patients with AgP (24 females and 8 males; mean age $34.78 \pm 6.42$ years) were consecutively selected. The patients were divided into 2 groups as localised $\mathrm{AgP}$ (LAgP) and generalised AgP (GAgP). Monocyte counts, high-density level (HDL) count and monocyte/HDL ratios (MHR) were recorded from the patients' blood samples. Mean Plaque index, bleeding on probing, periodontal pocket depth and clinical attachment level were recorded before treatment. The relationship between monocyte to HDL ratios and clinical attachment level between the groups were analysed by Spearman correlation.

Results: Sixteen GAgP and $16 \mathrm{LagP}$ patients were included in the study. The mean MHR values for the $\mathrm{LAgP}$ and $\mathrm{GAgP}$ groups were $9.87 \pm 2.85$ and $13.43 \pm 4.64$, respectively; there was a statistically significant difference between the groups $(\mathrm{p}<0.05)$.

Conclusion: The increased MHR values in patients with severe periodontitis may be one of the pathogenic mechanisms underlying the link between periodontal and cardiovascular diseases. Although we observed statistically significant differences between the MHR values in both groups, a larger sample size is needed to confirm the results of this study in the future.

Öz

Amaç: Hiperlipidemi, kardiyovasküler hastalıklar için bilinen bir risk faktörüdür. Kardiyovasküler hastalıklar gibi sistemik durumlar ile periodontal hastalıklar arasında ortak bir biyolojik mekanizma olduğu gösterilmiştir. Bu çalışmanın amacı, kan lipid profili ile agresif periodontitis (AgP) şiddeti arasındaki ilişkiyi incelemektir. 
Gereç ve Yöntemler: AgP tanısı almış toplam 32 sistemik sağlıklı hasta (24 kadın ve 8 erkek; ortalama yaş: $34,78 \pm 6,42)$ çalışmaya dahil edildi. Hastalar lokalize (LAgP) ve generalize agresif periodontitis (GAgP) olarak iki gruba ayrıldı. Hastalardan alınan kan örneklerinde monosit sayıları, yüksek yoğunluklu lipoprotein seviyesi (HDL) sayımı ve monosit/HDL oranları (MHR) kaydedildi. Ortalama plak indeksi, sondlamada kanama, periodontal cep derinliği ve klinik ataşman seviyesi tedavi öncesinde kaydedildi. Monosit ile HDL oranları arasındaki ilişki ile gruplar arasındaki klinik bağlanma düzeyi arasındaki ilişki Spearman korelasyonuyla analiz edildi.

Bulgular: On altı GAgP ve 16 LagP hastası çalışmaya dahil edilmiştir. LAgP ve GAgP grupları için ortalama MHR değeri sırasıyla $9,87 \pm 2,85$ ve $13,43 \pm 4,64$ olarak bulunmuştur ve gruplar arasında istatistiksel olarak anlamlı bir fark bulunmuştur ( $<<0,05$ ).

Sonuç: Şiddetli periodontitisli hastalarda MHR değerlerinde artış, periodontal hastalık ve kardiyovasküler hastalıklar arasındaki bağlantıların altında yatan patojenik mekanizmalardan biri olabilir. GAgP grubu arasında MHR değerlerinde istatistiksel olarak anlamlı farklılıklar gözlemlemiş olsak da, bu çalışmanın sonuçlarını doğrulamak için daha büyük bir örneklem büyüklüğü ile gelecekte yapılacak araştırmalara ihtiyaç vardır.

\section{Introduction}

Periodontitis is a chronic inflammatory disease caused by microbial-induced host-related inflammation, resulting in connective tissue and alveolar bone loss. Periodontal pathogens produce a local inflammatory response, including the exudation and migration of a large number of leukocytes $(1,2)$. Inflammatory response in the first line of defense against bacterial pathogens, such as monocytes/ macrophages, neutrophils, lymphocytes that are amplified due to pro-inflammatory mediators produced by various cells. The release of these substances into the bloodstream can trigger a host response with significant systemic inflammation (3).

Aggressive periodontitis (AgP) can lead to an improved host response and metabolic changes, such as increased C-reactive protein (CRP) serum level. In addition, chronic systemic inflammatory stimulation by untreated periodontal disease has been shown to increase neutrophil and lymphocyte levels in patients (3).

Studies have shown that systemic inflammation associated with periodontitis may be associated with the pathogenesis of inflammatory diseases such as atherosclerosis and cardiovascular disease (CVD) $(4,5)$. Although chronic inflammation plays a clear role in the pathogenesis of both diseases, it has been reported that changes in lipoproteins and lipoprotein metabolism may be important. Periodontal disease modifies lipoprotein metabolism to provoke atherosclerosis and CVD (6). Although chronic inflammation causes various changes in serum lipid and lipoprotein levels, one of the most known changes is a decrease in high-density lipoprotein cholesterol (HDL-C) level (7). In addition to the reduction in HDL-C level, chronic inflammation also causes changes in the composition of HDL-C (8). Changes in inflammation-induced HDL-C reduce the ability of HDL-C to participate in reverse cholesterol, lowdensity lipoprotein (LDL) transported and protected from oxidation. Generalized AgP (GAgP) patients have a higher atherogenic lipoprotein profile than control groups (9).

The increased number of monocytes is associated with atherosclerosis and the HDL-C molecule may prevent the activation and proliferation of monocytes. It has been shown that the monocyte count/HDL-C ratio (MHR) may be superior to the individual monocyte count or HDL-C level, and that increased MHR may be a predictive marker for the development and progression of atherosclerosis and therefore for cardiovascular events (10). Stable coronary artery disease (CAD) in order to estimate the severity of coronary atherosclerosis in patients with CAD, the newly introduced MHR can be used to predict the severity of inflammation, however, there is no data on the relationship of this parameter to the severity of periodontitis in the literature review.

$\mathrm{AgP}$ is a serious form of periodontitis characterized by rapid attachment loss and bone destruction in healthy adolescents and young adults (11). Research has shown some mechanisms in the pathogenesis of $\mathrm{AgP}$, such as specific microbial environments, hypersensitive monocytes and macrophages that increased inflammatory mediator levels, specific genetic risk factors and altered host defense are not associated with a specific systemic marker with periodontal destruction.

The aim of this study was to determine the relationship between the severity of periodontal inflammation and MHR in AgP patients, as a result of the established relationship between periodontitis and atherosclerosis and the severity of periodontitis. 


\section{Materials and Methods}

Between May 2018 and November 2018, AgP patients admitted to Kütahya University of Health Sciences Turkey, Faculty of Dentistry, Department of Periodontology were included in the study. Patients were enrolled according to the following criteria: at least 18 years of age, no pregnancy, lack of systemic disease (endocrinological disorders such as autoimmune disease, diabetes) and bisphosphonates. Before the study, clinical procedures and blood sampling were explained and all subjects gave written consent in accordance with the 1975 Declaration of Helsinki, which was revised in 2000. The study protocol was approved by the Local Ethic Committee (decision no: 2019/03).

Blood values and Periodontal index values that were requested before treatment were evaluated retrospectively on the data of $\mathrm{AgP}$ patients who applied to our clinic in 2018. Periodontal indices and orthopantomograph data were retrospectively analyzed. Periodontal clinical measurements included the following indices: plaque index (PI) (12), probing bleeding (BOP), probing depth (PD) and clinical attachment level (CAL). Clinical parameters were measured with a Williams probe calibrated in millimeters at four sites per tooth (mesio-buccal, buccal, disto-buccal and lingual).

Patients with periodontitis were diagnosed with AgP according to the 1999 Consensus Periodontal Disease Classification in accordance with the latest Consensus report on the identification of cases of periodontitis (11-13). We have identified patients with AgP as evidence of a healthy condition (except periodontitis), familial aggregate, rapid binding loss and bone destruction. AgP patients were classified as localized AgP (LAgP) or GAgP with the number of affected teeth (LAgP: first molar/cutter tooth presentation localized with interproximal binding loss on at least two permanent teeth, one of which was the first molar) and not including more than two teeth except for the first molar and incisor teeth: GAgP: loss of generalized interproximal attachment affecting at least three permanent teeth other than the first molar and incisor teeth.

\section{Statistical Analysis}

The data were analyzed using the software program (SPSS for Windows v. 20.0 Statistical
Package, USA). All parameters were analyzed by Kolmogorov-Smirnov test to determine normal or abnormal distribution. Student's t-test was used for normal distribution and Mann-Whitney $U$ test was used for abnormal distribution. The relationships between PD, CAL parameters and MHR values were evaluated using Pearson correlation coefficients (r). To demonstrate the sensitivity and specificity of MHR, as well as the cut-off value to estimate the severity of the periodontal disease, the recipient study characteristics [receiver operating characteristic (ROC)] curve was used. $p$ value less than 0.05 was considered statistically significant. The power was calculated $80 \%$ when there was 17 patient per each AgP group, using the $\alpha$ value as 0.05 (14).

\section{Results}

Initially, 33 patients with AgP were included in this study. A subject was excluded from the study because of the diagnosis of Von Willebrand's disease. A total of 32 systemic healthy patients ( 24 females and 8 males; mean age $34.78 \pm 6.42$ years) with $\mathrm{AgP}, 16$ with $\mathrm{LAgP}$ and 16 with GAgP were consecutively selected. Two patients were smoking in each AgP group. Table 1 summarizes the demographic data of the patients included in the study groups.

There were statistically significant differences between the LAgP and GAgP groups for PI, BOP, PD and CAL. The GAgP group had more severe clinical index measurements than the LAgP group. Patients with GAgP had significantly higher monocyte counts than patients with LAgP. HDL-C levels did not show a statistically significant difference between the groups (Table 2).

The mean MHR values for the LAgP and GAgP groups as shown in Table 3 were $9.87 \pm 2.85$ and $13.43 \pm 4.64$, respectively. For this value, there was a statistically significant difference between the $\mathrm{AgP}$ groups $(p=0.015)$.

\begin{tabular}{|l|l|l|}
\hline \multicolumn{3}{|l|}{ Table 1. Demographic data } \\
\hline Group & GAgP (n=16) & LAgP $(\mathbf{n = 1 6 )}$ \\
\hline Age (year) & $35.19 \pm 5.97$ & $34.38 \pm 7.01$ \\
\hline Female/male (\%) & $12 / 4(75 \% / 25 \%)$ & $12 / 4(75 \% / 25 \%)$ \\
\hline Smoking (10> per a day) & 2 & 2 \\
\hline $\begin{array}{l}\text { GAgP: Generalized aggressive periodontitis, LAgP: Localized aggressive } \\
\text { periodontitis }\end{array}$ \\
\hline
\end{tabular}


ROC analysis was performed to determine MHR cut-off value. This value in the admission for the severity of predictive disease in the study group was 9.88 with $0.75 \%$ sensitivity and $0.5 \%$ specificity (area below the curve was $0.734, p=0.024$ ) (Figure 1 ).

Spearman correlation analysis did not show a significant relationship between the CAL parameter and the MHR value $(r=0.315, p=0.080)$.

\section{Discussion}

Monocytes are the most important sources of pro-inflammatory and antioxidant cytokines in inflammatory sites (10). In contrast, HDL-C has antiinflammatory and anti-oxidant effects. It is thought that MHR may be used as a new marker for predicting CVD severity due to combining two detrimental processes such as inflammation and oxidative stress $(10,15,16)$. MHR is positively correlated with CRP levels and its role in systemic inflammation is supported by studies presented $(10,17)$. Recently, MHR has been reported to be a new marker for major adverse outcomes in heart disease $(15,18)$.

To our knowledge, this study is a pilot study showing the relationship of MHR with AgP severity. In this cross-sectional study, the association of MHR values with disease severity in generalized and

\begin{tabular}{|c|c|c|c|}
\hline & GAgP $(n=16)$ & LAgP ( $n=16)$ & p \\
\hline PI & $1.56 \pm 0.56$ & $1.07 \pm 0.59$ & $0.022^{*}$ \\
\hline PD & $4.17 \pm 0.69$ & $3.02 \pm 0.49$ & $0.000 *$ \\
\hline BOP (\%) & $89.37 \pm 10.28$ & $63.06 \pm 23.48$ & $0.000 *$ \\
\hline CAL & $5.12 \pm 0.69$ & $3.60 \pm 0.97$ & $0.000 *$ \\
\hline Monocyte $\left(x 10^{3}\right)$ & $0.58 \pm 0.17$ & $0.43 \pm 0.09$ & $0.017^{*}$ \\
\hline $\mathrm{HDL}-\mathrm{C}(\mathrm{mg} / \mathrm{dL})$ & $45 \pm 10.31$ & $45.38 \pm 10.02$ & 0.918 \\
\hline \multicolumn{4}{|c|}{$\begin{array}{l}\text { PI: Plaque index, PD: Probing depth, BOP: Bleeding on probing, CAL: } \\
\text { Clinical attachment level, HDL-C: High-density lipoprotein Count, } \\
\text { GAgP: Generalized aggressive periodontitis, LAgP: Localized aggressive } \\
\text { periodontitis Mann Whitney U analyes were used }\end{array}$} \\
\hline
\end{tabular}

localized AgP patients was evaluated. In the GAgP group, MHR values were significantly higher and MHR values greater than 9.88 were found to be a risk markers for GAgP.

One study reported that increased PD is significantly associated with elevated CRP concentrations, and that the surface area or volume of periodontal lesion in AgP patients is the most determinant of serum CRP levels and therefore a correlation between periodontal destruction and systemic inflammation is supported (2).

According to Nibali et al. (19), both the leukocyte counts and the serum lipid levels of the subjects participating in the study were related to their periodontal status. A trend was observed for dose dependence of periodontitis as an exposure: higher inflammatory (leukocyte counts) and metabolic markers (LDL levels) appeared in people with more general disease. D'aiuto et al. (3) in patients with periodontitis, the number of leukocytes increased in relation to the presence of deep periodontal pocket.

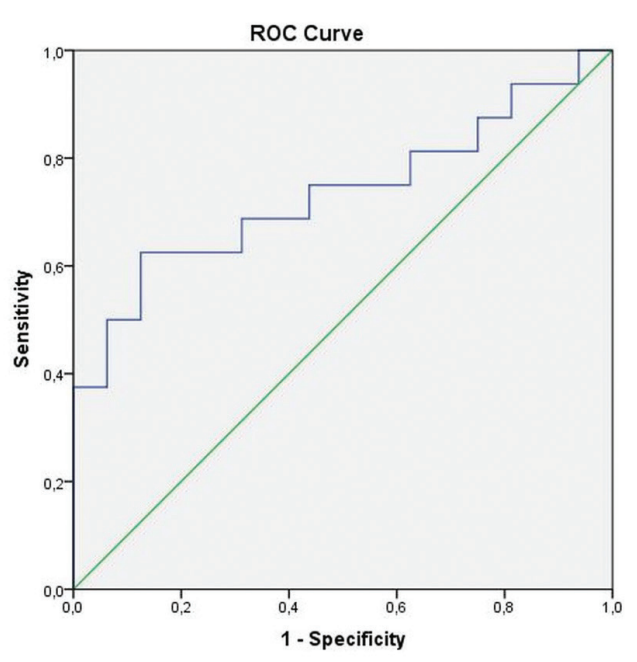

Figure 1. Area under the curve analysis ROC: Receiver operating characteristic

Table 3. Monocyte count to high-density lipoprotein ratio

\begin{tabular}{|l|l|l|l|l|l|} 
& GAgP $(\mathbf{n = 1 6 )}$ & LAgP $(\mathbf{n = 1 6 )}$ & $\mathbf{p}$ & \multicolumn{2}{|l}{$\mathbf{9 5 \%}$ confidence interval of the difference } \\
\hline MHR ratio & $13.43 \pm 4.64$ & $9.87 \pm 2.85$ & 0.015 & Lower & Upper \\
\cline { 5 - 6 } & & & 6.3675 & 0.7474 \\
\hline
\end{tabular}


According to these findings, significantly higher monocyte counts were observed in the GAgP group of our study.

Gao et al. (20) showed that HDL-C levels of patients with GAgP were significantly lower than those of healthy controls, whereas Davies et al. (21) reported that serum lipid concentrations were not significantly different in individuals with AgP compared to controls. The discrepancy between these studies may be a result of the severity of periodontal inflammation and differences in age and ethnicity distribution. HDL-C levels were not significantly different in our study groups.

Bacterial lipopolysaccharides leading to hypersensitive phenotype resulting from the production of proinflammatory cytokines may increase serum lipid levels. Increased proinflammatory cytokines in periodontitis may contribute to the pathogenesis of hyperlipidemia (22). Kırzıoğlu et al. (23) in this study, HDL-C levels in the periodontitis group were higher than in the periodontal healthy group. It has been reported that HDL-C may become dysfunctional and its anti-inflammatory and antithrombotic functions decrease in inflammatory conditions and chronic diseases. Fentoglu et al. (24) showed that HDL-C levels were higher in gingivitis than in periodontitis and this difference was attributed to the role of inflammation rather than infection.

Our study has some limitations, first of all, the study had a cross-sectional design, so this study could not give a definite conclusion about the role of MHR in severe periodontal diseases. Secondly, since the effect of body weight on both inflammatory and metabolic markers is clear, we see that this variable is not a limitation in our study. Third, the number of patients was relatively small and larger studies were needed to clarify the relationship between MHR and periodontal status. Fourth, study design did not have periodontal healthy controls to compare MHR values. The lack of information on CVD and HDL-related family history, obesity, physical activity and dietary habits is an limitation of the study. Considering these conditions in future studies on MHR may give more explanatory information about obtaining MHR values.

The assumption that a relationship between AgP and CVD may be caused by genetic susceptibility to hyperinflammatory responses led our study population to the form of $\operatorname{AgP}$ (25). Furthermore, it was concluded that the genetic susceptibility locus was shared by both $\mathrm{AgP}$ and heart diseases. above mentioned study.

The result of this study, in which MHR may be affected by AgP as a new cardiovascular risk factor, may lead to significant clinical results. These findings will not only facilitate identification of persons at risk of losing their teeth due to severe periodontal disease, but will also allow early interventions to prevent or reduce the severity of CVD. Future studies will focus on the effect of periodontal treatment on MHR values.

\section{Conclusion}

MHR values in patients with severe periodontitis may be one of the underlying pathogenic mechanisms of the connections between periodontal disease and CVD. This may be particularly alarming in young individuals represented by AgP patients who may contribute to early or faster CVD in susceptible patients with periodontal disease-associated higher MHR values.

Although we observed statistically significant differences in the MHR values between the GAgP groups, a larger sample size is needed to confirm the results of this study.

\section{Ethics}

Ethics Committee Approval: The study protocol was approved by the Kütahya University of Health Sciences Turkey, Faculty of Medicine non-interventional Ethic Committee (decision no: 2019/03).

Informed Consent: Participants signed the written informed consent form.

Peer-review: Externally peer-reviewed.

\section{Authorship Contributions}

Concept: K.O., B.G., Design: K.O., B.G., Data Collection or Processing: B.G., K.O., Analysis or Interpretation: B.G., Literature Search: E.D., B.G., Writing: E.D.

Conflict of Interest: No conflict of interest was declared by the authors.

Financial Disclosure: The authors declared that this study received no financial support.

\section{References}

1. D’aiuto F, Nibali L, Parkar M, Patel K, Suvan J, Donos N. Oxidative stress, systemic inflammation, and severe periodontitis. J Dent Res 2010; 89: 1241-6. 
2. Salzberg TN, Overstreet BT, Rogers JD, Califano JV, Best AM, Schenkein HA. C-reactive protein levels in patients with aggressive periodontitis. J Periodontol 2006; 77: 933-9.

3. D'aiuto F, Nibali L, Parkar M, Suvan J, Tonetti M. Short-term effects of intensive periodontal therapy on serum inflammatory markers and cholesterol. J Dent Res 2005; 84: 269-73.

4. Ramirez-Tortosa M, Quiles J, Battino M, Granados S, Morillo $J M$, Bompadre $S$, et al. Periodontitis is associated with altered plasma fatty acids and cardiovascular risk markers. Nutr Metab Cardiovasc Dis 2010; 20: 133-9.

5. Ford PJ, Yamazaki K, Seymour GJ. Cardiovascular and oral disease interactions: what is the evidence? Prim Dent Care 2007; 14: 5966.

6. Griffiths R, Barbour S. Lipoproteins and lipoprotein metabolism in periodontal disease. Clin Lipidol 2010; 5: 397-411.

7. Feingold KR, Grunfeld C. Effect of inflammation on HDL structure and function. Curr Opin Lipidol 2016; 27: 521-30.

8. Feingold KR, Grunfeld C. The effect of inflammation and infection on lipids and lipoproteins in Endotext. MDText. com, South Dartmouth, Mass, USA; 2015.

9. Rufail ML, Schenkein HA, Barbour SE, Tew JG, van Antwerpen R. Altered lipoprotein subclass distribution and PAF-AH activity in subjects with generalized aggressive periodontitis. J Lipid Res 2005; 46: 2752-60.

10. Kundi H, Kiziltunc E, Cetin M, Cicekcioglu H, Cetin ZG, Cicek G, et al. Association of monocyte/HDL-C ratio with SYNTAX scores in patients with stable coronary artery disease. Herz 2016; 41: 523-9.

11. Armitage GC. Development of a classification system for periodontal diseases and conditions. Ann Periodontol 1999; 4: 1-6.

12. Silness J, Loe H. Periodontal disease in pregnancy II. Correlation between oral hygiene and periodontal condition. Acta Odontol Scand 1964; 22: 121-35.

13. Tonetti M, Claffey N, European Workshop in Peridontology group C. Advances in the progression of periodontitis and proposal of definitions of a periodontitis case and disease progression for use in risk factor research: Group C Consensus report of the 5th European workshop in periodontology. J Clin Periodontol 2005; 32(Suppl 6): 210-3.

14. Löe H, Brown LJ. Early onset periodontitis in the United States of America. J Periodontol 1991; 62: 608-16.
15. Canpolat U. Monocyte-to-HDL-cholesterol ratio and left atrial remodelling in atrial fibrillation. Europace 2017; 19: 1409.

16. Kanbay M, Solak Y, Unal HU, Kurt YG, Gok M, Cetinkaya H, et al. Monocyte count/HDL cholesterol ratio and cardiovascular events in patients with chronic kidney disease. Int Urol Nephrol 2014; 46: 1619-25.

17. Kundi H, Gok M, Kiziltunc E, Cetin M, Cicekcioglu H, Cetin ZG, et al. Relation between monocyte to high-density lipoprotein cholesterol ratio with presence and severity of isolated coronary artery ectasia. Am J Cardiol 2015; 116: 1685-9.

18. Canpolat U, Aytemir K, Yorgun H, Şahiner L, Kaya EB, Çay S, et al. The role of preprocedural monocyte-to-high-density lipoprotein ratio in prediction of atrial fibrillation recurrence after cryoballoon-based catheter ablation. Europace 2015; 17: 1807-15.

19. Nibali L, D'aiuto F, Griffiths G, Patel K, Suvan J, Tonetti MS. Severe periodontitis is associated with systemic inflammation and a dysmetabolic status: a case-control study. J Clin Periodontol 2007; 34: 931-7.

20. Gao H, Tian Y, Meng H, Hou J, Xu L, Zhang L, et al. Associations of apolipoprotein $\mathrm{E}$ and low-density lipoprotein receptor-related protein 5 polymorphisms with dyslipidemia and generalized aggressive periodontitis in a $\mathrm{C}$ hinese population. J Periodontal Res 2015; 50: 509-18.

21. Davies $R$, Jaedicke $K$, Barksby $H$, Jitprasertwong P, Al-Shahwani RM, Taylor JJ, et al. Do patients with aggressive periodontitis have evidence of diabetes? A pilot study. J Periodontal Res 2011; 46: 663-72.

22. Andrukhov O, Haririan $H$, Bertl K, Rausch WD, Bantleon HP, Moritz $A$, et al. Nitric oxide production, systemic inflammation and lipid metabolism in periodontitis patients: possible gender aspect. J Clin Periodontol 2013; 40: 916-23.

23. Kırzıoğlu FY, Fentoğlu Ö, Bulut MT, Doğan B, Özdem M, Özmen Ö, et al. Is a Cholestrol-Enriched Diet a Risk Factor for Alveolar Bone Loss? J Periodontol 2016; 87: 529-38.

24. Fentoglu O, Kale Köroglu B, Kara Y, Doğan B, Yılmaz G, Sütçü $\mathrm{R}$, et al. Serum lipoprotein-associated phospholipase A2 and C-reactive protein levels in association with periodontal disease and hyperlipidemia. J Periodontol 2011; 82: 350-9.

25. Schaefer AS, Richter GM, Groessner-Schreiber B, Noack B, Nothnagel M, El Mokhtari NE, et al. Identification of a shared genetic susceptibility locus for coronary heart disease and periodontitis. PLoS Genet 2009; 5: e1000378. 